\title{
Geoacumulation of Heavy Metals in Sediment of the Fluvial-Lagoon-Deltaic System of the Palizada River, Campeche, Mexico
}

\author{
Gabycarmen Navarrete-Rodríguez ${ }^{1}$, María del Refugio Castañeda-Chávez ${ }^{*}$, and Fabiola Lango- \\ Reynoso $^{1}$ \\ 1 Tecnológico Nacional de México/Instituto Tecnológico de Boca del Río, Carretera Veracruz, Boca del Río, \\ Veracruz; gabycarmennavarrete@bdelrio.tecnm.mx (N-R.G); mariacastaneda@itboca.edu.mx (C-C.M.R); \\ fabiolalango@bdelrio.tecnm.mx (L-.R.F) \\ * Correspondence: mariacastaneda@itboca.edu.mx
}

\begin{abstract}
The fluvial-lagoon-deltaic system of the Palizada river in Campeche is an ecosystem of socioeconomic and ecological importance. It is justifiable to carry out studies in this system, due to its connection with another larger ecosystem called Términos lagoon. The objective of this investigation was to analyze the concentration of $\mathrm{Pb}$ and $\mathrm{Cd}$ in sediments of the fluvial-lagoondeltaic system of the Palizada river and to determine, with this, the contamination index of these metals. Cd presented the highest concentration in sampling sites and climatic seasons with respect to $\mathrm{Pb}$, with a maximum value of $53.926 \pm 5.045$, while $\mathrm{Pb}$ was $10.421 \pm 0.218 \mu \mathrm{g}$ g- 1 . The same tendency was presented with pollution and geoaccumulation indexes, where the $\mathrm{Cd}$ index stands out. The enrichment of heavy metals was identified through the accumulation of $\mathrm{Cd}$ and $\mathrm{Pb}$, such process was evaluated through the geoacumulation index (Igeo). The results of this indicated that these elements are contaminating with an anthropogenic origin mainly. This element represents a toxic risk for the Palizada system, due to its high toxicity even at low concentrations, as well as to evaluate the sublethal effects in organisms that inhabit this system and it requires the implementation of an integral monitoring.
\end{abstract}

Keywords: pollution sources; sediments; Palizada river; heavy metals

\section{Introduction}

Sediments are important deposits of pollutants such as heavy metals and pesticides. They play an important role in the remobilization of pollutants in aquatic systems under favorable conditions and in water-sediment interactions [1]. In the case of heavy metals, these elements reach rivers when their partial dissolution occurs, their transfer to water and living organisms is the result of physical and chemical changes in river conditions [2]. In water, most suspended particles tend to bind to heavy metals and form complexes, which precipitate in the sediment where they accumulate gradually [3].

The quality of coastal lagoon sediments depends on anthropogenic activities related to land use and proximity to agricultural areas [4]. However, the presence of these in the environment occurs naturally, since all marine soils and sediments contain trace metals as natural constituents and these are leached into water at low concentrations [5]. In aquatic ecosystems, heavy metals and trace are incorporated from natural and anthropogenic sources. These are considered some of the most important environmental pollutants to be known due to their toxicity, persistence and tendency to accumulate in aquatic organisms [6].

The dynamics of movement between sediment and water becomes a cycle of distribution of metals, in greater proportion for sediments, since once trace elements are released in the water column, they bioaccumulate in aquatic sediments. Its dynamics depend on environmental conditions, such as the water cycle, seasonal variations, $\mathrm{pH}$, microorganisms, sediment reduction, and oxidation potential $[7,8]$. Other research indicates that the highest concentration of heavy metals reported in 
sediments is the result of their high concentration in water, which represents an ecological threat to fauna in aquatic bodies, since they are easily adsorbed on the surface of the sediment [9].

In estuaries and coastal wetlands, sediments protect a variety of pollutants, mainly heavy metals. Therefore, they can serve as an enriched source of these elements for benthic organisms [10]. Organisms exposed to heavy metals can be induced to undergo physiological and biochemical changes [11]. The process of mobilization of heavy metals in sediment will depend mainly on the composition of the sediment, its content of organic matter, size and grain texture [12]. The importance of analyzing the concentration of heavy metals in sediments of fluvial-lagoon systems in Mexico is due to the fact that the results of this work will indicate their quality, as well as the long-term effect on biota and public health. This work aimed to establish the concentration of metals in sediments of the fluvial-lagoon-deltaic system of the Palizada river in Campeche, and thus to determine its quality according to the index of contamination of the elements evaluated.

\section{Materials and Methods}

\subsection{Study area}

The fluvial-lagoon-deltaic system of the Palizada river is located in the southwest portion of the hydrological basin of the Términos lagoon, between the geographic coordinates 181'슬 "and

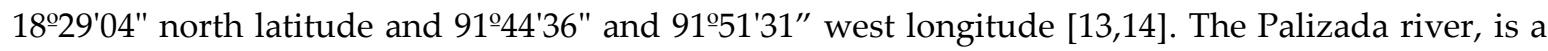
tributary of the Usumacinta River, it is separated from the latter, at the point known as Boca de Amatitlán located approximately $25 \mathrm{~km}$ from the Palizada city, the river of the same name traverses southwest-northeast the municipality and its flow is unloaded in Boca Chica of the Términos Lagoon $[15,16]$. Términos lagoon being a coastal type, forms part of this lagoon fluvial system. It is one of the most widely studied ecosystems, including the rivers that converge in it. It is worth noting that it was decreed as a protected natural area in 1994 [14]. Also, it is important to mention that the Palizada river system contributes an important flow volume to the Términos lagoon with $240 \mathrm{~m} 3 \mathrm{~s}-1$, followed by the Chumpan river with $35 \mathrm{~m} 3 \mathrm{~s}-1$ and the Candelaria river with $2 \mathrm{~m}^{3} \mathrm{~s}^{-1}$ [13]. There are three prevailing climatic conditions a year in the region of the system. The turbulence season from October to January, which is when there are strong north and northwest winds with an average speed of 8.3 $\mathrm{m}^{3} \mathrm{~s}^{-1}[17,18]$. The dry season from February to May, winds blow predominantly from the northwest at speeds of 4-6 m s-1 and the currents in the lagoon are overcome by the tide, which produces a greater seawater input. Whereas, in the rainy season from June to September, there is an increase in water supplied by the rivers $[13,14]$. Sampling sites to sediment of the fluvial-lagoon-deltaic system of the Palizada River, Campeche (Figure 1). Samples were collected with a dredge and stored in polyethylene bags to be transported to laboratory at temperatures of $4^{\circ} \mathrm{C}$, then these were preserved in freezing.

\subsection{Laboratory analysis}

Samples obtained in the field were processed in the Instituto Tecnológico de Boca del Río (ITBOCA), in areas of the Aquatic Resources Research Laboratory. Once the samples were extracted, they were stored in hermetically sealed food grade polyethylene bags and kept frozen until freezedried in a Thermo Savant ModulyOD-114 unit for 72 hours at $-49^{\circ} \mathrm{C}$ and a vacuum pressure of 36x103 mbar. The lyophilized samples were stored in a desiccator until acid digestion analysis. 

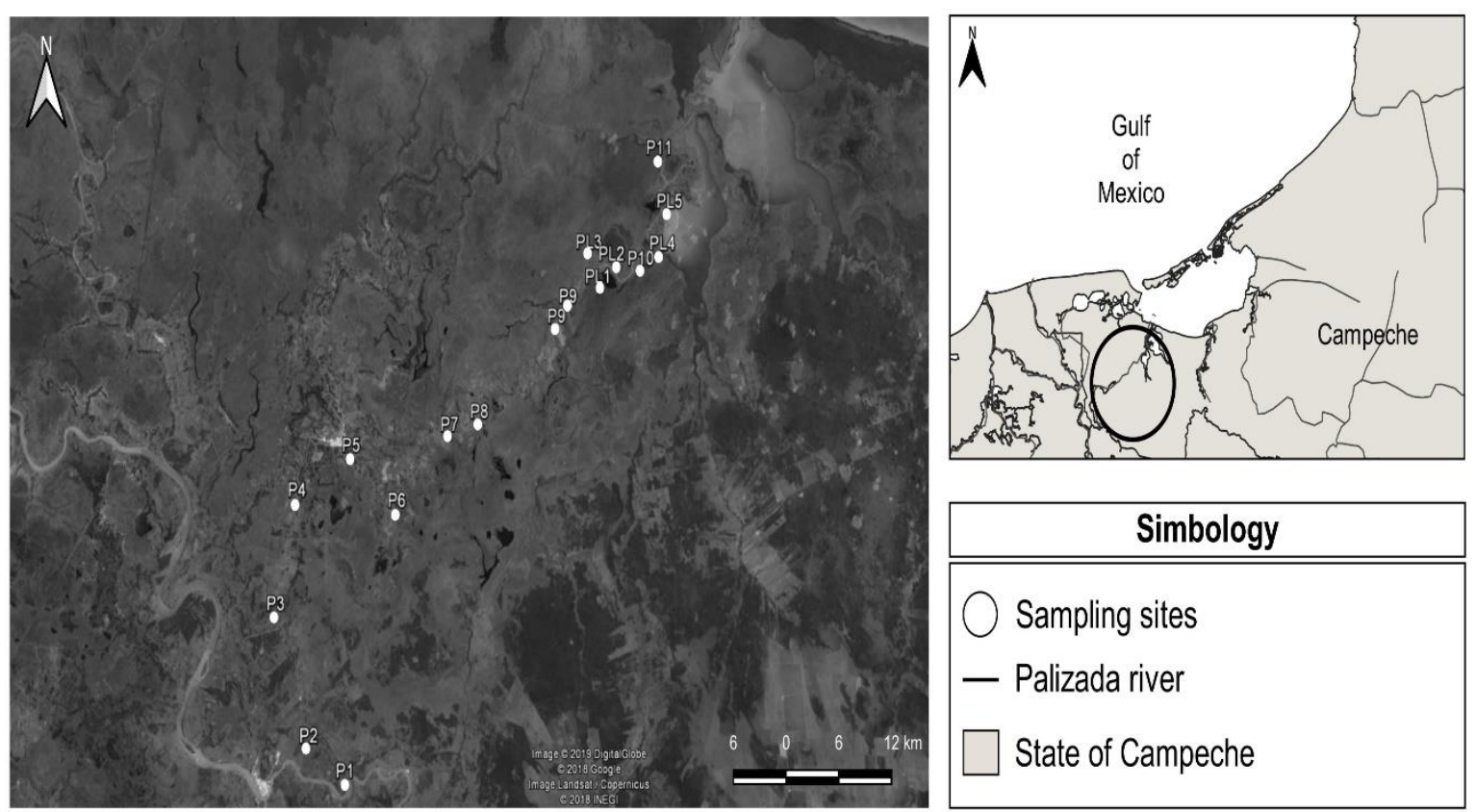

Figure 1. Sampling sites to sediment of the fluvial-lagoon-deltaic system of the Palizada River, Campeche, Mexico.

\subsection{Acid digestion in a microwave}

The preparation of the material used in the analysis was carried out in accordance with the specifications for heavy metal analysis NOM-117-SSA1-1994 [19].The laboratory material was washed using neutral phosphate-free Extran ${ }^{\circledR}$ soap, then soaked in a solution of nitric acid HNO3 (JTBaker ${ }^{\circledR}$ ) at $20 \%$ for 24 hours, after which it was washed with deionized water, dried with hot air and finally it was stored. The digestion of each lyophilized sample was carried out in a microwave equipment CEM Mars 5 (CEM, Corporation Mathews, NC, USA). Using 0.5 grams of sample, in addition $9 \mathrm{ml}$ of reactive grade $\mathrm{HNO} 3$ was added. Then, two ramps with a pressure of 120 and 100 PSI were programmed in a microwave at a temperature of $150^{\circ} \mathrm{C}$ and $190^{\circ} \mathrm{C}$ for 5 and 10 minutes, respectively. The digestion was performed by batch process with a blank sample and a positive control. Once the microwave digestion was complete, Millipore ${ }^{\circledR}$ nitrocellulose filters of $0.45 \mu \mathrm{m}$ were used and the filtrate was made up to a volume of $25 \mathrm{ml}$ with deionized water (Milli-Q), the final extract was deposited in amber polyethylene vial and stored at a temperature of $4^{\circ} \mathrm{C}$.

To perform quantification of heavy metals, a Thermo Scientific iCE 3500 AAS (Thermo Scientific ${ }^{\circledR}$, China) was used. Certified standards, High Purity Standards (High-Purity Standards, Charleston, SC), were used in the preparation of the calibration curve for the quantification of metals, with a correlation coefficient greater than 0.99 . The concentrations of heavy metals in sediment were studied by sampling site and season, these were analyzed with Statistica 7.0 software (StatSoft, Inc. Tulsa, U.S.A.), and a one-way analysis of variance was also used. A multiple comparison test of Tukey was performed afterwards to determine the significant difference $(p<0.05)$.

2.4. Heavy metal enrichment: Pollution Load Index (PLI) for heavy metals and geoaccumulation index (Igeo)

For the calculation of the Contamination Factor metal (CF), the relationship between metal content in a sediment sample and normal concentration levels was considered, based on this, the level of contamination of the sediment was determined. To calculate the CF of sediments in the study area, the contamination of trace metals was taken into account, from the global average crustal, according to background values. It is considered that this factor will reflect the enrichment of the metal in sediment when $\mathrm{CF}>1$, for a particular metal, means that the sediment is contaminated by the element. If $\mathrm{CF}<1$, it expresses that there is no or low contamination of the metal, product of natural and anthropogenic inputs. It was used $1 \leq \mathrm{CF} \leq 3$ for moderate contamination; $3 \leq \mathrm{CF} \leq 6$ for a considerable 
contamination and $\mathrm{CF}>6$ for a very high contamination [20-22]. The above was made according to the following relationship:

$$
C F=\text { Contamination factor metal content in sediment } / \text { Base metal value }
$$

The environmental quality of the sediments was evaluated with the Pollution Load Index (PLI) integrated for heavy metals, also known as the Metal Content Index with the acronym (MCI). Where, $\mathrm{n}$ is the number of metals analyzed and CF is defined as the concentration of a metal in a contaminated sediment divided by the normal value in an uncontaminated environment (background values) [23,24].

$$
P L I=(C F 1 \times C F 2 \times C F 3 \ldots . C F n)^{\left(\frac{1}{n}\right)}
$$

The enrichment of sediments with metallic elements was analyzed by means of the geoaccumulation index (Igeo), this is a quantitative measure of contamination of metals in aquatic sediments, comparing the contents of current metals with preindustrial levels; this index was introduced by Müller [25,26]. This indicator reflects the degree of sediment contamination by a metal [27]. The I-geo provides a simple and fast method to determine the extent of sediment contamination of a lake or river bed by loading trace elements into sediments above background values, but does not provide further information to the mobilization and bioavailability of the trace element $[26,28]$. The value of the geoaccumulation index is described by the following equation:

$$
\text { Igeo }=\log _{2} \frac{[C n]}{k \times B n}
$$

Where $\mathrm{Cn}$ is the measured concentration of the element $\mathrm{n}$ (number of metals) in the soil tested, $\mathrm{Bn}$ is the geochemical background value of the element $\mathrm{n}$ in average crust; here the average metal content in the earth's crust of $(X) \mathrm{mg} k g-1$, while $\mathrm{k}=1.5$, to consider possible variations in the background data due to the lithogenic effects (constant factor), to take into account natural fluctuations of a substance given in the environment, as well as very small anthropogenic influences $[28,29]$. Bn reference values were taken from Huheey [29]. Seven grades or classes of the geoaccumulation index were proposed with the following types: Class 0 (practically uncontaminated): I-geo $<0$; Class 1 (uncontaminated to moderately contaminated): $0<\mathrm{I}$-geo $<1$; Class 2 (moderately contaminated): $0<$ Igeo $<2$; Class 3 (moderate to highly contaminated): $2<$ Igeo $<3$; Class 4 (highly contaminated): $3<$ Igeo $<4$; Class 5 (highly contaminated to extremely contaminated): $4<$ Igeo $<5$; Class 6 (extremely contaminated): $5<$ Igeo. Finally, class 6 is an open class and comprises all values of the index higher than class $5[27,31]$.

\section{Results and discusion}

\subsection{Sources of heavy metals in the Palizada river system}

The sediments of an aquatic system reflect the environmental quality of an ecosystem, they are fundamental in the dynamics of distribution and accumulation of pollutants, as heavy metals [2]. These elements are released to the environment and have contact with aquatic systems through a process of wet or dry deposition, erosion and/or by direct downloads of anthropogenic activities, which are carried out in collective areas [32].

In the Palizada system, in addition to traditional fishing, there is also industrial activity as it is the extraction of crude oil, which is certainly the main source of economic income in the region [33]. In contrast, Aguilar et al. [34] highlighted that on both sides of the Palizada, Chumpán and Candelaria rivers in Campeche, the main economic activity is agriculture which, as a consequence of the use of agrochemicals, provides heavy metals to the streams of these rivers. 
An important factor in the distribution of heavy metals in the Palizada river corresponds to the hydrological conformation of the fluvial-lagoon-deltaic system of the river, since it is made up of numerous internal lagoons, which are influenced by the anthropogenic contribution of livestock and agricultural activities that take place south of its margins $[6,34,35]$.

Different types of heavy metals inputs to the aquatic ecosystems show their wide distribution in the system. This is the case of the fluvial-lagoon-deltaic system of the Palizada river, where, the $\mathrm{pb}$ and cd were identified in all the sampling sites analyzed in the present investigation. The contribution of metals is also associated with the dynamics of the Palizada river system. As a consequence, the suspended ground materials generate an increase in the turbidity and contribute with a great amount of sediments to the Términos lagoon [33]. In accordance to the above mentioned, Paéz-Osuna et al., 1987; Grenz et al., 2017 noted that the Palizada river contributes with an average percentage of 92\% of the total contribution of heavy metals that are downloaded in the lagoon and, as such, variations in the proportion of each metal concentration are presented $[33,36]$.

The sediments can accumulate heavy metals that reach aquatic environments, in which changes in physicochemical conditions can be remobilized and in doing so, releasing these elements in the water column, these contributions can be transferred through the food chain [2,14]. The Palizada system interacts with surrounding aquatic bodies presenting dynamics of material distribution to the Términos lagoon. In which the water column, in its totality, acts as a sink for nutrients, due to a high production of particles, dissolved organic matter and a reduced export of material to the Gulf of Mexico [37]. As a consequence, in the Términos lagoon, a spatial and temporary heterogeneity of water-sediment flows predominates, with peaks in the mineralization rates during the rainy season, relating significantly to the content of organic matters in sediments [Grenz et al., 2019]. The above, according to Aguilar et al. [34] demonstrates the relationship between the Palizada river and the Términos lagoon, where there is a correlation in the content of organic matter, the texture of the sediment and the content of heavy metals. This, as a result of the proportions between the following: clay-organic matters (OM); sand-vanadio; $\mathrm{OM}-\mathrm{cu}$ and cu-clay. Therefore, it is observed that the mobilization and accumulation of heavy metals is influenced by the relationship between the Palizada river fluvial-lagoon system, the Términos lagoon and the Gulf of Mexico, indicating an interrelationship between the continental and coastal systems in the transportation of pollutants.

\subsubsection{Lead concentration $(\mathrm{Pb})$}

$\mathrm{Pb}$ presence and concentration in aquatic ecosystems can be related to different sources. For the Palizada river system, the sources are the high number of industrial activities such as exploration and extraction of hydrocarbons in the coastal area adjacent to the Términos lagoon, said activities that heavy metals associated with this activity can enter the lagoon [35]. The Palizada, Chumpán and Candelaria rivers, as well as some inland lakes such as Pom, Atasta, del Corte, San Carlos, del Este, Balchacah and Panlau, which flow to the south of the Términos lagoon, represent a source of agrochemicals among other pollutants [6]. In relation to the above, the ATSDR [39] noted that the presence of $\mathrm{Pb}$ in the environment, may be associated with its old uses in the area, with types of gasoline, paint and pesticide, which have had a significant impact on the amount of lead found in the ground. Once $\mathrm{Pb}$ is incorporated, it adheres strongly to particles in the soil and remains in the upper layer of the same. Subsequently, when these soil particles are mobilized by rainwater, small amounts of this element can be dragged into aquatic bodies, entering rivers, lakes and streams. Lead is an element that can remain attached to sediment and water particles for many years [14,39].

In sampling sites analyzed in the Palizada river system, the maximum $\mathrm{Pb}$ concentrations were presented in the points: LCAR with $10.421 \pm 0.218$, followed by LDUL2 with $9.190 \pm 0.801$; LDUL with $9.210 \pm 0.656$; S7 with $9.153 \pm 0.641$; S8 $9.138 \pm 0.542 \mu \mathrm{g}$ g- 1 (Figure 2). Duncan et al. [32] also identifyed that the enrichment and pollution processes with heavy metals like $\mathrm{Ni}, \mathrm{Cr}, \mathrm{Cd}$ and $\mathrm{Pb}$ in sediment of the Pra river basin in Ghana, represented an indicator of the development of anthropogenic activities in the basin. 


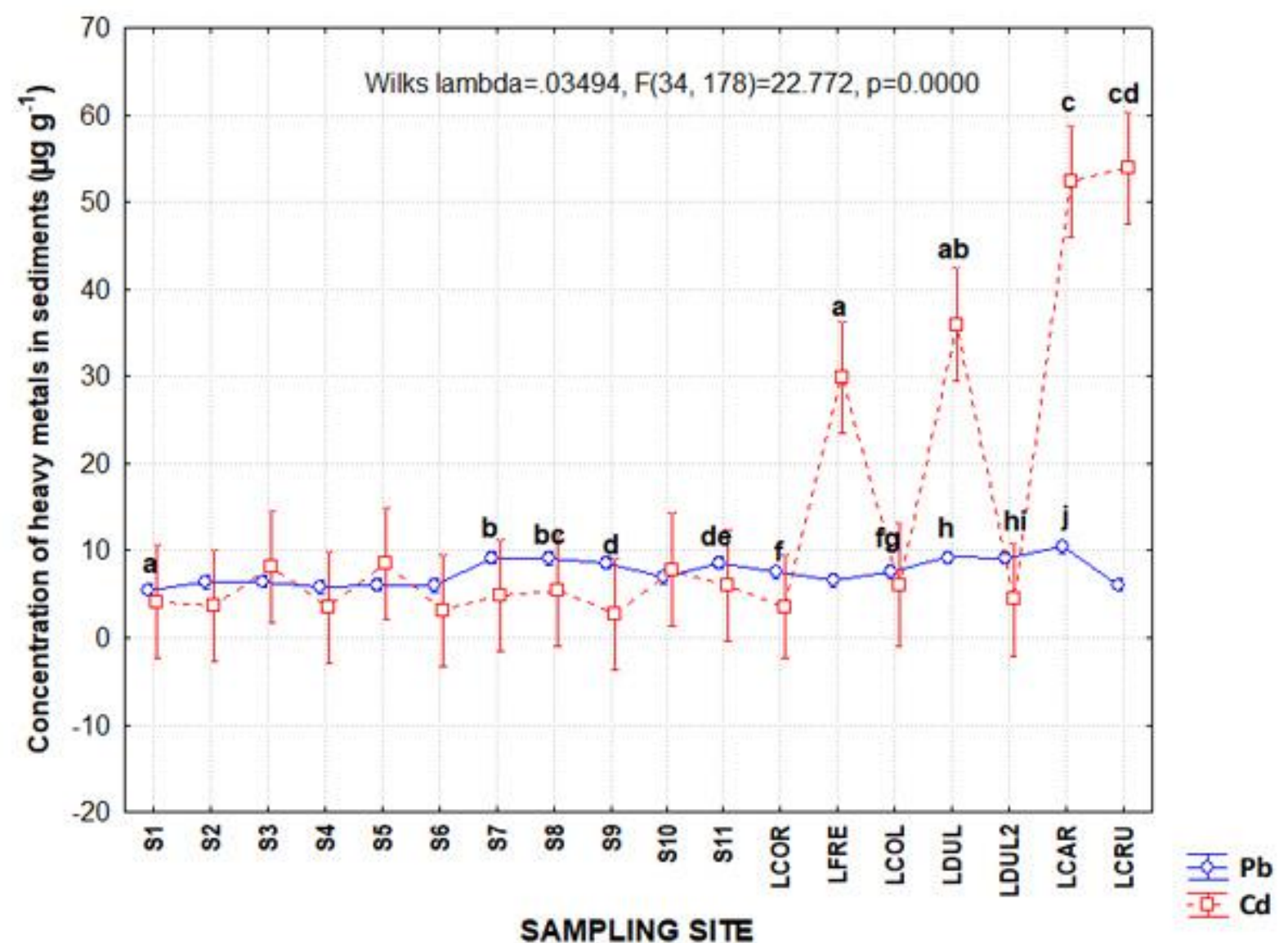

Figure 2. Concentration of heavy metals in sediment $\left(\mu \mathrm{g} \mathrm{g}^{-1}\right)$ from sampling sites of the fluvial-lagoondeltaic system of the Palizada river in Campeche. The different literals indicate significant differences between sampling sites. Abbreviations: LCOR-Corcho lagoon; LDUL-Dulce lagoon; LCAR-Carmen lagoon; LLAR-Larga lagoon; LCOL-Colorada lagoon; LCRU-Cruces lagoon; LFRE-Frente lagoon.

The minimum concentrations were in the following sites: S1 (5.515 \pm 1.013$)$; S4 (5.793 \pm 0.878$)$; S6 (6.010 \pm 1.607$) ; \mathrm{LCRU}(6.048 \pm 0.602)$. The sampling sites that showed significant statistical differences $(\mathrm{p}<0.05$ ) were: S1, S7, S9, LCOR, LDUL and LCAR (Table 1), however, there was overlap of means with sites S8, S11, among others. The concentrations reported in this investigation were higher than the values in other studies; Balakrishnan et al. [40] reported in the Muthupet lagoon in India, average concentrations of $\mathrm{Pb}$ that presented significant statistical differences $(p<0.05)$ with a range that varied from 0.312 to $1.220 \mu \mathrm{g} \mathrm{g}^{-1}$. Also, Ajima et al. [41] for Pb showed the same tendency, with a higher concentration of this element in sediments with respect to water, they reported an average concentration of $\mathrm{Pb}$ in sediment of $8.23 \pm 0.23 \mathrm{mg} \mathrm{kg}^{-1}$, whereas in the water samples it was $2.08 \pm 0.02$ $\mathrm{mg} \mathrm{kg}^{-1}$.

Table 1. Heavy metals concentration in sediment $\left(\mu \mathrm{g} \mathrm{g}^{-1}\right)$ of the fluvial-lagoon-deltaic system of the Palizada river in Campeche, Mexico.

\begin{tabular}{lll}
\hline Site & $\boldsymbol{P b}$ & $\boldsymbol{C d}$ \\
\hline S1 & $5.515 \pm 1.013$ & $4.141 \pm 0.554$ \\
S2 & $6.435 \pm 0.986$ & $3.615 \pm 0.684$ \\
S3 & $6.461 \pm 0.943$ & $8.076 \pm 1.696$ \\
S4 & $5.793 \pm 0.878$ & $3.456 \pm 0.853$ \\
S5 & $6.081 \pm 0.926$ & $8.538 \pm 1.664$ \\
S6 & $6.010 \pm 1.607$ & $3.126 \pm 1.469$ \\
S7 & $9.153 \pm 0.641$ & $4.826 \pm 1.329$
\end{tabular}




\begin{tabular}{lll} 
S8 & $9.138 \pm 0.542$ & $5.446 \pm 0.941$ \\
S9 & $8.606 \pm 0.919$ & $2.721 \pm 0.404$ \\
S10 & $6.915 \pm 0.628$ & $7.835 \pm 1.088$ \\
S11 & $8.598 \pm 0.813$ & $6.028 \pm 2.101$ \\
LCOR & $7.494 \pm 0.824$ & $3.527 \pm 0.972$ \\
LFRE & $6.545 \pm 1.143$ & $29.803 \pm 19.865$ \\
LCOL & $7.578 \pm 1.025$ & $6.066 \pm 1.318$ \\
LDUL & $9.210 \pm 0.656$ & $35.973 \pm 25.388$ \\
LDUL2 & $9.190 \pm 0.801$ & $4.371 \pm 0.639$ \\
LCAR & $10.421 \pm 0.218$ & $52.426 \pm 6.525$ \\
LCRU & $6.048 \pm 0.602$ & $53.926 \pm 5.045$ \\
Total & $7.510 \pm 1.684$ & $13.526 \pm 18.185$ \\
\hline
\end{tabular}

$\mathrm{Pb}$ concentrations in the rainy and north winds seasons showed significant statistical differences $(p<0.05)$. The maximum concentration of this metal was in the dry season with $8.208 \pm 1.362$, while the minimum was presented in the north winds season with a concentration of $6.695 \pm 1.760 \mu \mathrm{g} \mathrm{g}^{-1}$ (Figure 3). Variations in metal concentrations per season, occur because during dry season there is an increase in the rate of evaporation and salinity, associated with high temperaturas [13]. While in stormy weather (north winds) the winds help to mix the water column and its nutrients and with this, the resuspension of sediments and also with the washing of the soil surface [13,32].

Furthermore, the Fe of the Palizada river system showed an increase in concentrations during the dry season, suggesting the existence of evaporation phenomena and low mobility of the sediments [14]. Also, during this season there is a decrease in the flow of water from the rivers to the Términos lagoon, this favors the entry of seawater [13]. The aforementioned reflects that the Palizada river, during the north winds season, presents a greater interaction of continental and marine water, this allows to register this aquatic body as an extremely dynamic system [42].

Also, Montalvo et al. [2] showed emphasis on the difficulty of differentiating between the origin of anthropogenic contributions and natural contributions of an aquatic ecosystem, highlighting that the increase in concentrations between seasons is an important element for pollution analysis. In the same study area, the importance of the climatic season and sediment characteristics as essential elements for the mobilization and transport of heavy metals; stressing the influence of the season with variations in concentrations of elements analyzed $(p<0.05)$ in the Palizada river [6]. Separately, In the Muthupet lagoon, $\mathrm{Pb}$ concentrations presented a significant difference $(p<0.05)$, as well as a range of 0.312 to $1.220 \mu \mathrm{g} \mathrm{g}^{-1}$ [40]. The maximum $\mathrm{Pb}$ value was $1.220 \mu \mathrm{g} \mathrm{g}^{-1}$ in station 1 of the monsoon season and the minimum value of $0.312 \mu \mathrm{g}$ g- 1 was observed in station 2 of the post-monsoon season, while an average range of lead was recorded with $3.457 \mu \mathrm{g} \mathrm{g}^{-1}$ at the station during the entire study period. In the Passur river in Bangladesh, showed an average $\mathrm{Pb}$ concentration of 6.919, with maximum values of 12.200 in June and $11.710 \mathrm{mg} \mathrm{Kg}^{-1}$ in May. Meanwhile, in the remaining months the concentrations of this element had the following distribution: $1.035 ; 1.110 ; 6.480 ; 8.980 \mathrm{mg} \mathrm{Kg}^{-1}$ for January, February, March, April, respectively [43]. Differences in heavy metal concentrations between seasons can be associated with variations in environmental conditions and discharges of pollutants. 


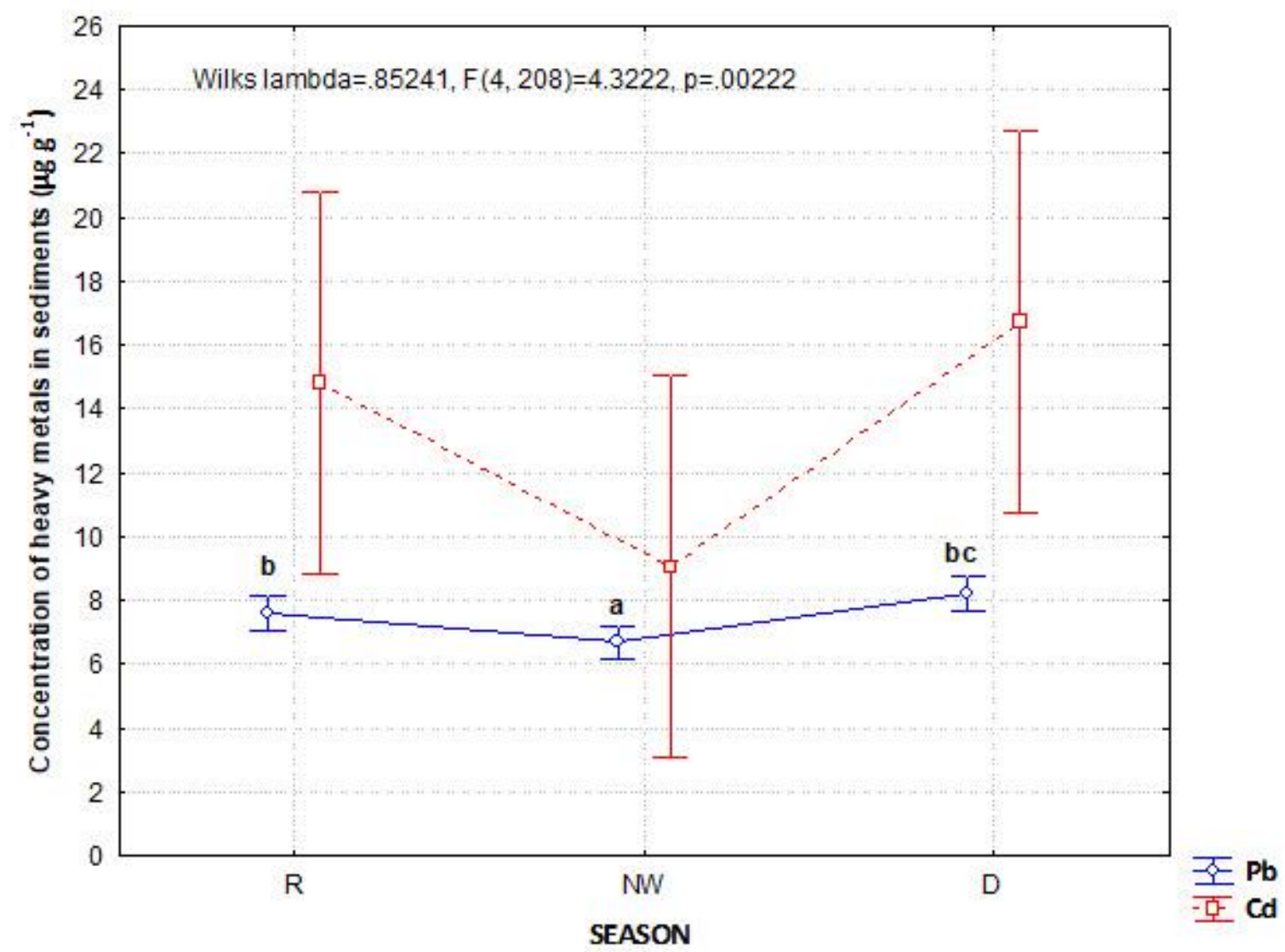

Figure 3. Concentration of heavy metals in sediment ( $\mu \mathrm{g}$ g-1) by season of the fluvial-lagoon-deltaic system of the Palizada river in Campeche, Mexico. Abbreviations: R = Rainy season (March-May); NW = North Winds season (June-September) and D: Dry season (October-February).

A seasonal variation in levels of metal accumulation in environmental matrixes of water, sediment and biota [44]. They also pointed out that the concentrations in water and sediments are generally higher in summer than in autumn, and that the discharge of leachates in the summer from streams should be considered. Meanwhile, the differences in metal concentration can be attributed to the spatial and temporal heterogeneity of heavy metal distribution, especially when related to the variability introduced by wastewater and fluvial discharges [45].

Confirmed that the climatic season has a high influence on the variability of metal concentrations in their analysis [6]. They also reported that the highest levels of $\mathrm{Cu}, \mathrm{Fe}$ and $\mathrm{Mn}$ were found during the dry season, which may be due to the occurrence of significant evaporation phenomena in the area. In the Gorgan Bay in Iran, also noticed that the concentrations of metals such as $\mathrm{Al}, \mathrm{Cu}, \mathrm{Fe}, \mathrm{Ni}, \mathrm{Pb}$, and $\mathrm{Zn}$ presented significant statistical differences $(p<0.05)$ due to seasonal and spatial variations in sites of sampling [46]. Meanwhile, the deposition of heavy metals takes place after a period of time and at a greater distance from the discharge zone, which suggests that there is mobilization and balance between the two matrixes [47]. Pb concentrations between climatic seasons in this investigation showed an opposite behavior when registering the maximum concentration in the dry season (Table 2). 
Table 2. Concentration of heavy metals, lead $(\mathrm{Pb})$ and cadmium $(\mathrm{Cd})$ in sediment $\left(\mu \mathrm{g} \mathrm{g}^{-1}\right)$ per season of the fluvial-lagoon-deltaic system of the Palizada river in Campeche, Mexico.

\begin{tabular}{lll}
\hline Season & $P b$ & $C d$ \\
\hline R & $7.626667 \pm 1.589706$ & $14.80139 \pm 19.05778$ \\
NW & $6.695556 \pm 1.760489$ & $9.04389 \pm 13.39202$ \\
D & $8.208056 \pm 1.362015$ & $16.73556 \pm 20.87021$ \\
Total & $7.510093 \pm 1.684916$ & $13.52694 \pm 18.18557$ \\
\hline
\end{tabular}

\subsubsection{Cadmium concentration $(\mathrm{Cd})$}

The presence of $\mathrm{Cd}$ in the ecosystems is explained by several sources, emphasizing that some fertilizers contain it and is filtered to the soil during its application in crops [14,48]. The different sources of $\mathrm{Cd}$ origin and the characteristics of the sediment are associated with the maximum concentration values that appear in sampling sites. Cd presented a maximum of $53.926 \pm 5.045 \mu \mathrm{g}$ 1 , while $\mathrm{Pb}$ maximum value was $10.421 \pm 0.218 \mathrm{\mu g} \mathrm{g}^{-1}$. According to the above ATSDR [48] Cd adheres strongly to organic matter, which remains immobile in soil and can be incorporated by plants, and thus enter the food chain.

By sampling site, the highest concentrations of $\mathrm{Cd}$ for the following sites were: LCRU $53.926 \pm$ 5.045; LCAR 52.426 \pm 6.525 ; LDUL $35.973 \pm 25.388$; LFRE $29.803 \pm 19.865 \mu \mathrm{g}$ g-1. While the sites with the lowest concentrations of Cd were: S9 $2.721 \pm 0.404$; S6 3.126 \pm 1.469 ; S4 3.456 \pm 0.853 ; LCOR 3.527 $\pm 0.972 \mu \mathrm{g} g-1$. In contrast to the results of this research, Montalvo et al. [14] reported significant difference by climate season and not by sampling site for most of the metals analyzed in the same study area. $\mathrm{Cd}$ maximum and minimum values, showed significant statistical differences $(\mathrm{p}<0.05)$ among the LFRE-LDUL and LCAR-LCRU sites, that is, these pairs of sampling sites presented an overlap of means (Figure 2). The rest of the sampling sites, such as S1 to S11, LCOR, LCOL and LDUL2, did not report significant statistical differences $(p>0.05)$. The average concentrations in the Palizada river in this investigation were higher compared to other investigations carried out in this same area, such as the one [2], reported that $\mathrm{Cd}$ maximum concentrations during the rainy season were $2.34 \mu \mathrm{g}$ g-1, followed by 2.261 in the north winds season and the dry season with $1.60 \mu \mathrm{g}$ g- 1 (Table 2). The variations in the concentrations can be attributed to differences in levels of introduction of this element to the aquatic environment, which occur by anthropogenic route and by dragging pollutants from a source that generates it.

$\mathrm{Cd}$ for each season did not show significant statistical difference $(p>0.05)$, which is related to studies reported that this can be associated with a constant contribution of this element to the Palizada river, throughout the year [34]. The dry season in the present investigation showed a maximum concentration of $16.735 \pm 20.870$, followed by the rainy season with $14.801 \pm 9.057$ and in the north winds with $9.043 \pm 13.392 \mu \mathrm{g}$ g- 1 . The previous concentrations were higher than those reported by Aguilar et al. [34] in rivers, such as the Palizada with 0.283, Chumpan with 0.266 and Candelaria with $0.233 \mu \mathrm{g}$ g- 1 , the climatic season has a greater influence on the presence and distribution of some heavy metals.

The difference in metal concentration can be associated with the type of element, $\mathrm{Cd}$ presented difference between seasons, in contrast to $\mathrm{Pb}$. There were coincidences in sites with maximum values of $\mathrm{Pb}$ and $\mathrm{Cd}$ for LCAR and LDUL sites, while the minimum concentrations were for sites $\mathrm{S} 1$ and $\mathrm{S} 6$. The similarity in the behavior of metals is these sites could be associated with common sources of these elements and characteristics of the metal. Likewise, the analysis of sediments in an aquatic ecosystem provides a comprehensive assessment of a site contamination [2,34]. Sediments are main receptors due to the precipitation of most of the pollutants deposited in the water column. The presence of maximum concentrations of both metals, is relevant information for its effects on public health, because they are not required for metabolism and are toxic in low concentrations $[14,34]$.

3.2. Geoaccumulation index (I-geo) in the Palizada river 
The LCAR site presented maximum values of Igeo Cd with a value of 7.4395 , this positioned it in class 6 with Igeo $>5$, which is classified as extremely contaminated. In the case of $\mathrm{Pb}$ in the same place, it also showed maximum values of both CF of 0.8337 and Igeo with -0.847 , placing it in class 0 classified as practically uncontaminated (Table 3). The Igeo values showed that $\mathrm{Cd}$ contributes with the highest enrichment of all the elements analyzed, which showed that there was high contamination in sediments of analyzed sites during the two periods of study [49]. The highest levels of Cd may be related to the increase in human and industrial activities in the vicinity of the lagoon in this study, however $\mathrm{Pb}$ concentrations were lower than those reported in other investigations. The results of Igeo in the dry season according to Duncan et al. [32] showed different contamination levels of the Ghana river, of which the $\mathrm{Cd}$ values stood out as unclogged to highly polluted and the $\mathrm{Pb}$ was moderately to extremely contaminated, while the $\mathrm{Cr}$ values were considered as moderately contaminated. Differences in metal values indicated a variability of heavy metal enrichment sources. In contrast to the previous, quantified concentrations of $\mathrm{Cd}$ in some of the sites analyzed in their research were included in the class of I-geo 1 (uncontaminated to moderately contaminated). Meanwhile, other sites also analyzed were cataloged within the class of I-geo 3 (moderate to heavily polluted) [50,51].

Table 3. Contamination Factor (CF), Pollution Load index (PLI) and Geoaccumulation Index (Igeo) of metals in sediments of the fluvial-lagoon-deltaic system of the Palizada river, Campeche, Mexico.

\begin{tabular}{llllll}
\hline $\begin{array}{c}\text { Sampling } \\
\text { site }\end{array}$ & CF Pb & CF Cd & PLI & I-geo Pb & I-geo Cd \\
\hline Total & 0.600807 & 67.6347 & 71.6510 & -1.35794 & 4.582834 \\
S1 & 0.441200 & 20.7083 & 15.0392 & -1.78611 & 3.775756 \\
S2 & 0.514800 & 18.0750 & 15.6939 & -1.55716 & 3.567886 \\
S3 & 0.516933 & 40.3833 & 35.0029 & -1.54940 & 4.721585 \\
S4 & 0.463467 & 17.2833 & 13.0882 & -1.70930 & 3.484867 \\
S5 & 0.486533 & 42.6917 & 34.6377 & -1.63929 & 4.804263 \\
S6 & 0.480800 & 15.6333 & 11.5489 & -1.68577 & 3.234434 \\
S7 & 0.732267 & 24.1333 & 28.8840 & -1.03748 & 3.961379 \\
S8 & 0.731067 & 27.2333 & 32.9581 & -1.03901 & 4.163699 \\
S9 & 0.688533 & 13.6083 & 15.2824 & -1.13040 & 3.168147 \\
S10 & 0.553200 & 39.1750 & 35.7353 & -1.44387 & 4.695075 \\
S11 & 0.687867 & 30.1417 & 35.1003 & -1.13035 & 4.245239 \\
LCOR & 0.599543 & 17.6357 & 17.4653 & -1.33059 & 3.509457 \\
LFRE & 0.523600 & 149.0167 & 138.7598 & -1.53620 & 6.061159 \\
LCOL & 0.606240 & 30.3300 & 30.9667 & -1.31768 & 4.310325 \\
LDUL & 0.736800 & 179.8667 & 227.5107 & -1.02875 & 6.145055 \\
LDUL2 & 0.735200 & 21.8583 & 26.7162 & -1.03327 & 3.852355 \\
LCAR & 0.833733 & 262.1333 & 360.9054 & -0.84757 & 7.439508 \\
LCRU & 0.483867 & 269.6333 & 216.6729 & -1.63851 & 7.484308 \\
\hline
\end{tabular}

The same trend was presented with higher I-geo $\mathrm{Cd}$ values with respect to $\mathrm{Pb}$ in the study area of this research (Figure 4), which was reported with a minimum value of $\mathrm{Pb}$ with -0.08 in the rainy season and in the case of $\mathrm{Cd}$ a maximum value of 5.75 in the dry season [49]. Also reported in the Tsurumi River, Japan, I-geo values for $\mathrm{Zn}, \mathrm{Cu}, \mathrm{Cd}, \mathrm{Pb}, \mathrm{Br}$ placing them in class 0 to 4 , which showed a sediment quality moderately to strongly contaminated [52]. The differences in sediment quality indexes such as Igeo, are indicators of the association between values obtained in the study area with permissible limits, to define the degree of contamination in the analyzed area (Figura 5). 


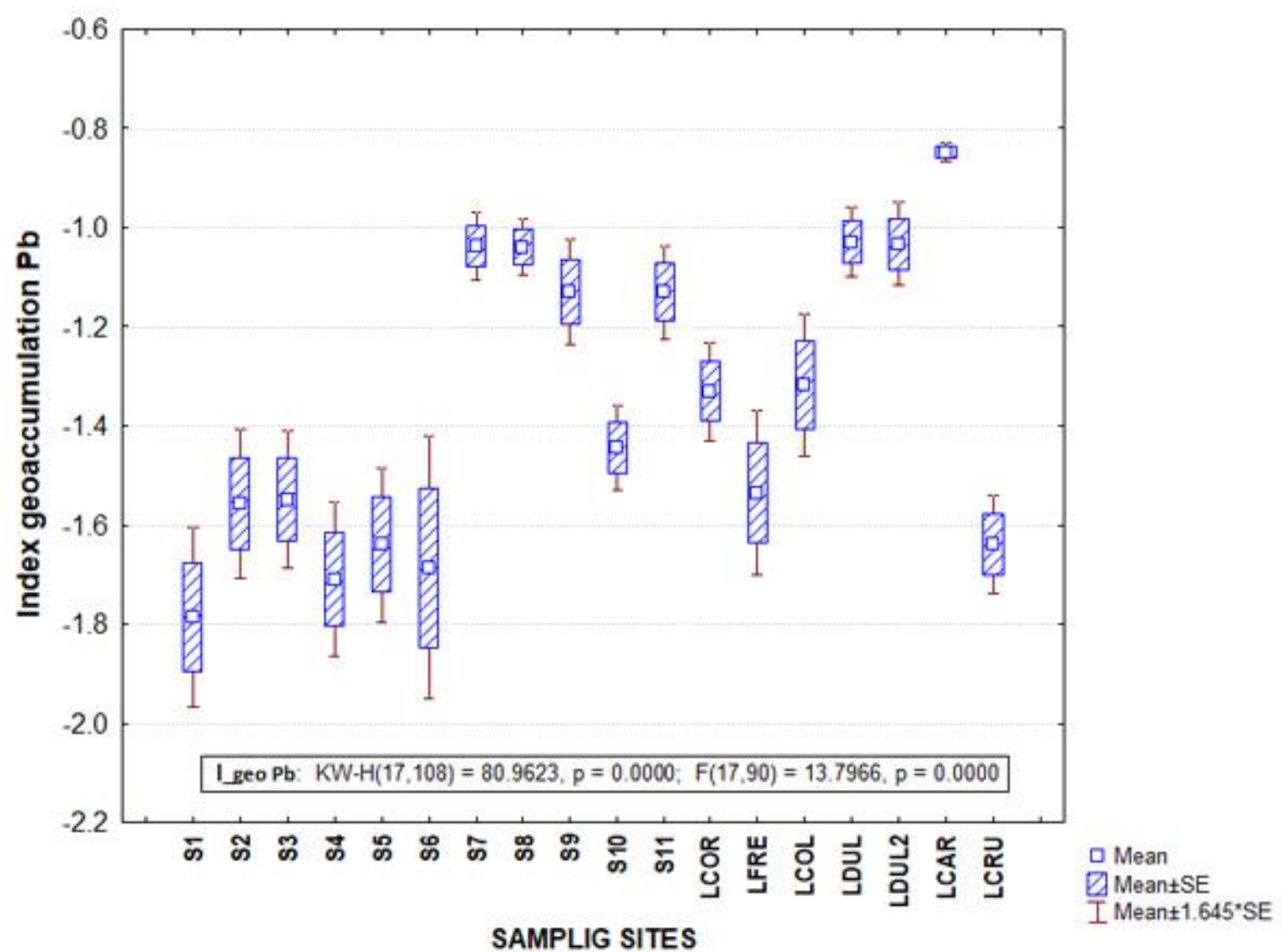

Figure 4. Igeo of heavy metal $(\mathrm{Pb})$ in sediments of the fluvial-lagoon-deltaic system of the Palizada river in Campeche, Mexico.

\subsection{Heavy Metal Pollution Load Index (PLI)}

The LCAR site presented maximum values of CF of Cd with 262.133 and PLI with 360.905, this metal contributed the highest value to the PLI. Cd also presented the maximum CF values in all the sampling sites analyzed. PLI values in the study area were higher than those reported by other investigations, such as those carried out in the Tsurumi river sediments, they reported an average PLI value of 4.88, minimum and maximum values of 1.24 and 7.65, respectively [52]. They noted that the reported levels of PLI confirmed that the quality of water and sediments are classified as contaminated and deteriorating, because they can have a severe impact on marine and coastal living conditions due to their effects on aquatic organisms.

Okan and Fevzi [53] reported lower values of PLI, but on the other hand they indicated variations between seasons with values of 0.04 to 4.63 during the fall, while in summer, spring and winter the minimum values were 0.01 , and the maximums of $6.74,8.45$ and 18.63 , respectively. Proving also, that higher levels of PLI in sampling sites can be associated with the discharge of wastewater; this coincides with the differences in values in this research and are related to pollution sources of this same nature. The use of metal contamination indexes can contribute to knowing the health status of an ecosystem, the PLI can provide some understanding of the quality of the environment, and that the trend in time and area also provides valuable information for making decisions about the pollution status of the area [54]. 


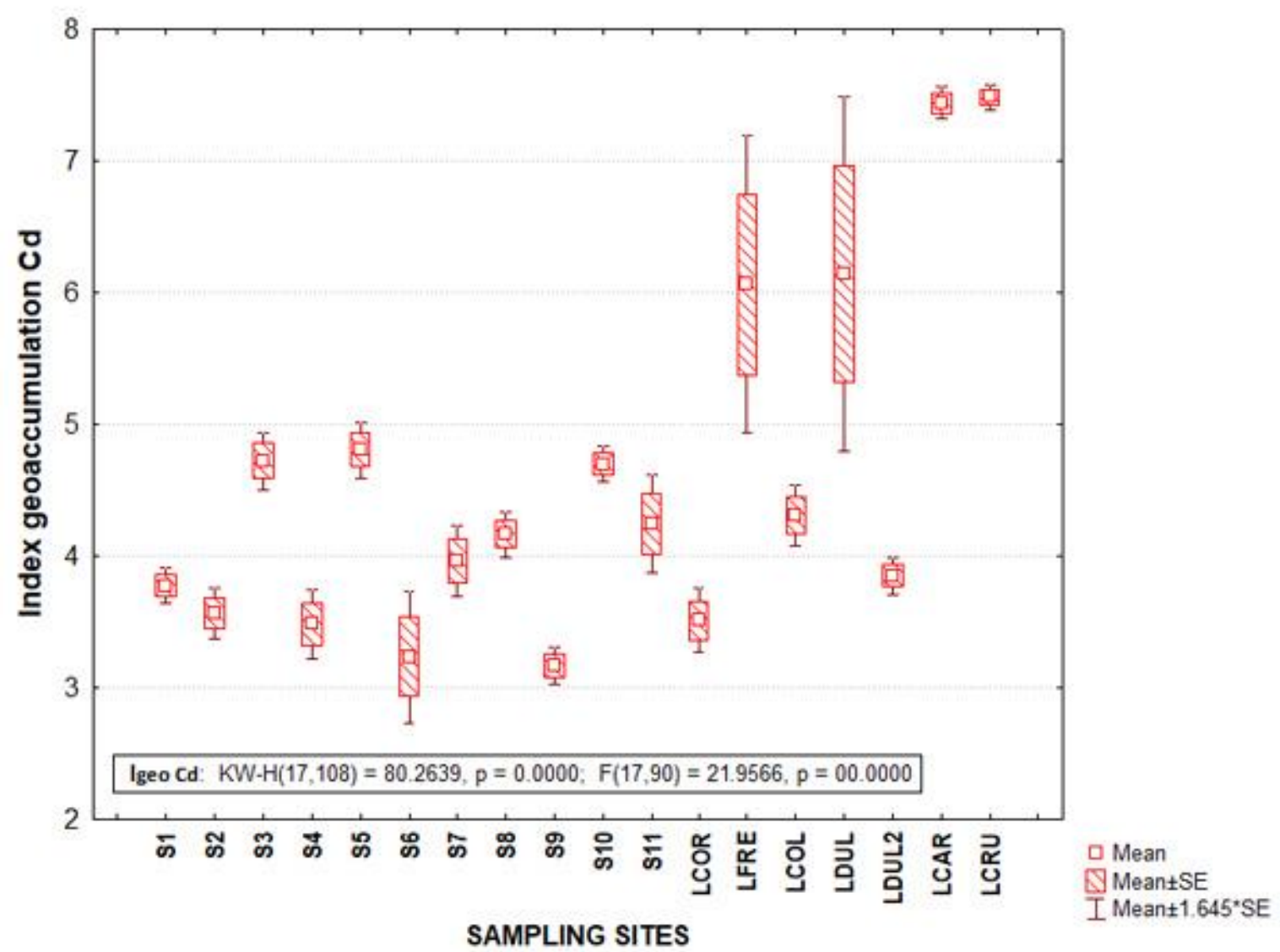

Figure 5. Igeo of heavy metal $(\mathrm{Cd})$ in sediments of the fluvial-lagoon-deltaic system of the Palizada river in Campeche, Mexico.

\subsection{Permissible limits in sediments}

Evaluating the presence of heavy metals in sediment is a tool that allows us to know the mobilization of these pollutants and their effects on biota. Taking into account, that sediments are a reservoir of heavy metals that contribute to the degree of bioavailability free for aquatic organisms. The migration of metallic compounds from the abiotic environment to aquatic organisms occurs in sediments, as well as their subsequent introduction and bioaccumulation in trophic chains $[39,55]$.

In the case of Mexico, there is no official legislation to regulate concentrations of metals in river sediments [56]. The use of international criteria such as that established by Long et al. [57] helps to deduce the minimum threshold concentrations (ERL) and maximum (ERM) of metals and metalloids that can produce adverse biological responses (Table 4). According to the comparison of the values of ERL, ERM, TRVs and TEL, Cd concentrations were the only ones that exceeded the established limits of the minimum and maximum thresholds, these results are an indicator of a potential risk for the fluvial-lagoon-deltaic system of the Palizada River by this metal (Table 4). The Palizada River Cd values exceed the limits established by the ERL, and were higher than international standards [6]. To emphasize the lack of national standards, Botello et al . [56] reported that they used the ERL value, established by the association of this angiosperm plant, with the sediment in grass Thalassia testudinum of prairies of the Términos lagoon system. In contrast, concentrations of $\mathrm{Pb}$ in all the sampling sites of this investigation were lower than values of ERL and TEL, since the maximum value recorded in the study area was $10.421 \pm 0.218 \mu \mathrm{g} \mathrm{g}^{-1}$. The aforementioned value was lower than the ERL of $46.7 \mu \mathrm{g} \mathrm{g}^{-1}$ [57], and mean of $34.08 \mathrm{mg} \mathrm{kg}^{-1}$ in sediment of China [58], which indicates that there is no acute risk, yet there coud be a chronic risk due to bioaccumulation of this element.

Other investigations pointed out differences between threshold values of sampling sites and metals. In sediments from estuaries of southwest India, the minimum values of ERL exceeded these levels in 25 stations for $\mathrm{Zn}$, in 29 for $\mathrm{Cd}, 34$ for $\mathrm{Ni}$ and in 41 sites for $\mathrm{Pb}$, these concentrations can cause adverse effects in biological organisms [21]. Pb values in this investigation were found within 
international ranges for sampling sites and seasons, in contrast those of $\mathrm{Cd}$, in some of these sampling points, surpassed these reference values (Table 4). Consequently, the study of sediments in an aquatic ecosystem allows an integral estimation of pollution, since they are the main receptors of most of the pollutants that are deposited in the water column [16,34].

Table 4. Permissible limits on the concentration of heavy metals in sediment ( $\left.\mathrm{mg} \mathrm{Kg}^{-1}\right)$.

\begin{tabular}{cccc}
\hline Permissible limits & $\mathbf{P b}$ & $\mathbf{C d}$ & Source \\
\hline Maximum permissible limit (MPL) & 0.040 & 0.006 & FEPA [59] \\
Probable effect concentrations (PEC) & 91.3 & 3.5 & CCME [60] \\
Interim Sediment Quality Guidelines (ISQG) & 35 & 0.6 & \\
Toxicity reference values (TRVs) & 31 & 0.60 & US EPA [61] \\
Minimum threshold concentration & 46.7 & 1.2 & \\
Effects Range-Low (ERL) & & & Long [57] \\
Maximum threshold concentration & 218 & 9.6 & \\
Effects Range-Median (ERM) & & & Buchman [62] \\
Threshold Effect Level (TEL) & 30.2 & 0.69 & MacDonald et al. [63] \\
Probable effects level (PEL) & 112.2 & 4.21 & \\
Threshold effects level (TEL) & 30.2 & 0.68 & \\
\hline
\end{tabular}

\section{Conclusion}

$\mathrm{Cd}$ concentrations obtained in sampling sites of the fluvial-lagoon-deltaic Palizada system presented values that exceeded the ERL and ERM, said reference values according to Long et al. (1995) for heavy metals, can cause biological effects in exposed marine organisms. Therefore, the presence in elevated concentrations of $\mathrm{Cd}$ in sediment in the zone indicates that they act as integrators of these elements and are a source of transfer to aquatic organisms. The differences in these concentrations and their association with different sources of pollution, hydrodynamic characteristics of the same system, and chemical properties of metals are highlighted.

On the other hand, $\mathrm{Pb}$ presented concentrations lower than the reference values, its presence means a source of chronic exposure for organisms that inhabit the study area. As well as its effect on the loss and condition of aquatic species, apart from the effect on public health through the trophic chain, and the socio-economic and environmental importance of this aquatic system.

In addition, I-geo $\mathrm{Pb}$ presented values lower than 1 , which allows them to be classified as noncontaminated. In contrast, values of I-geo $\mathrm{Cd}$ were in the range of moderately contaminated to highly contaminated in sampling sites analyzed, this indicates the existence of contributions with a fundamental androgenic origin with this element. The presence of both metals indicated the incorporation of these elements through diverse sources such as those of agrochemical type, the deposition of atmospheric and industrial pollutants, which together contribute to the enrichment of sediments in the analyzed zone. Due to the aforementioned, constant monitoring is required to help identify priority pollution sites to define the magnitude of anthropogenic influence, as well as to establish regulations and policies that reduce the use of compounds that contribute to the incorporation of heavy metals into the region.

Author Contributions: Research conceptualization and investigation: C-C.M.R and N-R.G; Literature search, data compilation and curation: C-C.M.R and L-R.F; Methodology, validation and data analysis: C-C.M.R. and N-R.G; Manuscript draft preparation: N-R.G and L-R.F; Further writing, review, and editing: C-C.M.R and LR.F; Supervision and project administration: C-C.M.R. and L-R.F.

Funding: This research was funded by CONACYT (Consejo Nacional de Ciencia y Tecnología) for the support granted to execute this work through Postdoctoral Stays linked to the Strengthening of the Quality of the National Postgraduate, CALL 2018 (1). 
Acknowledgments: To the Tecnológico Nacional de México/Instituto Tecnológico de Boca del Río (TecnM/ITBOCA), and CONACYT (Consejo Nacional de Ciencia y Tecnología) for the support granted to execute this work through Postdoctoral Stays linked to the Strengthening of the Quality of the National Postgraduate, CALL 2018 (1).

Conflicts of Interest: Declare conflicts of interest or state "The authors declare no conflict of interest."

\section{References}

1. Rashed, M. N. Monitoring of environmental heavy metals in fish from Nasser Lake. Environmental International. 2011, 27, 27-33.

2. Montalvo, C.; C, Aguilar.; J, Argaes.; R, M. Cerón.; J, G. Cerón.; L, E. Amador.; M, A. Ramírez. Cuantificación de los niveles de metales pesados en el río Palizada. (pp. 181-213). En: Villegas, Sierra. J.; R, M. Cerón Bretón (coord.). Análisis del Espacio Urbano y sus Consecuencias Ambientales en la Región de la Laguna de Términos. Universidad Autónoma de Campeche. 2018, 214.

3. Yilmaz, F.; Özdemir, N.; Demirak, A.; Tuna, A. L. Heavy metal levels in two fish species Leuciscus cephalus and Lepomis gibbosus. Food Chem. 2007, 100, 830-835.

4. Vargas, González. H H.; J. A. Arreola, Lizárraga.; J. García, Hernández.; R. A. Mendoza, Salgado.; T. Zenteno, Savín.; L. C. Méndez, Rodríguez. Calidad de sedimentos asociada a actividades antrópicas en lagunas costeras semiáridas subtropicales de la costa central este del Golfo de California. Rev. Int. Contam. Ambie. 2017, 33, 7-22. DOI: 10.20937/RICA.2017.33.esp02.01

5. Abdel-Ghani, S. A. Trace metals in seawater, sediments and some fish species from Marsa Matruh Beaches in north-western Mediterranean coast, Egypt. Egyptian J. of Aqua. Res. 2015, 41 (2), 145-154. DOI: 10.1016/j.ejar.2015.02.006

6. Montalvo, C.; C, A. Aguilar.; L, E. Amador.; J, G. Cerón.; R, M. Cerón. F Anguebes Atl V Cordova. Metal Contents in Sediments $(\mathrm{Cd}, \mathrm{Cu}, \mathrm{Mg}, \mathrm{Fe}, \mathrm{Mn})$ as Indicators of Pollution of Palizada River, Mexico. Environment and Pollution. 2014, 3(4), 89-98. DOI:10.5539/ep.v3n4p89

7. Cheng-xiu, Lu.; Jie-min, C. Speciation of Heavy Metals in the Sediments from Different Eutrophic Lakes of China. Procedia Eng. 2011,18, 318-23.

8. Zhang, L. Shi Z.; Zhang, J.; Jiang, Z.; Wang, F.; Huang, X. Spatial and seasonal characteristics of dissolved heavy metals in the east and west Guangdong coastal waters, South China. Mar Pollut Bull. Elsevier Ltd. 2015, 95(1) 419-26.

9. Milanov, Đ. R.; Krstić, P. M.; Marković, V. R.; Jovanović, A. D.; Baltić, M. B.; Ivanović, S. J.; Jovetić, M.; Baltić, Ž. M. Analysis of heavy metals concentration in tissues of three different fish speciesincluded in human diet from Danube River, in the Belgrade region, Serbia. Acta Veterinaria-Beograd. 2016, 66 (1), 89-102. DOI: 10.1515/acve-2016-0007

10. Wang, WX. Interactions of trace metals and different marine food chains. Mar. Ecol. Prog. Ser. 2002, 243, 295-309.

11. Ansari, TM.; Marr, IL.; Tariq, N. Heavy metals in marine pollution perspective: A mini review. J. Appl. Sci. 2004, 4, 1-20.

12. Magesh, N.S.; Chandrasekar, N., Krishna, Kumar. S.; Glory, M. Trace element contamination in the estuarine sediments along Tuticorin coast-Gulf of Mannar, southeast coast of India. Mar. Pollut. Bull. 2013, 73, 355-361.

13. Magallanes, Ordóñez. V. R.; A. J.Marmolejo, Rodríguez.; G. M. Rodríguez, Figueroa.; A. Sánchez, González.; S. Aguíñiga, García.; F. Arreguín, Sánchez.; M. Zetina, Rejón. A. Tripp, Valdez.; J. A. 
Romo, Ríos. Characterization of lithogenic and biogenic zones and natural enrichment of nickel in sediments of the Terminos Lagoon, Campeche, Mexico. Estuar Shelf Sci. 2014, 156, 116-123.

14. Montalvo, C.; C, Aguilar.; J, Argaes.; R, M. Cerón.; J, G. Cerón.; L, E. Amador.; M, A. Ramírez. Cuantificación de los niveles de metales pesados en el río Palizada. (pp. 181-213). En: Villegas, Sierra. J.; R, M. Cerón Bretón (coord.). Análisis del Espacio Urbano y sus Consecuencias Ambientales en la Región de la Laguna de Términos. Universidad Autónoma de Campeche. 2018b, 214.

15. Botello, A. V.; Páez, Osuna. F. El problema crucial: la contaminación. Serie de medio ambiente en Coatzacoalcos. Vol. 1 editado por centro de Eco desarrollo. México D.F. 1986, 62-85.

16. Gantús, Inurreta. F.; Alcalá, C.; Villanueva, L. Campeche. Historia breve. Fondo de Cultura Económica. México, D.F. 2011.

17. Fuentes-Yaco, C.; de Leon, D.A.S.; Monreal-Gomez, M.A.; Vera-Herrera, F. Environmental forcing in a tropical estuarine ecosystem: the Palizada River in the southern Gulf of Mexico. Mar. Freshwater Res. 2001, 52, 735-744.

18. Contreras Ruiz Esparza, A.; Douillet, P.; Zavala-Hidalgo, J. Tidal dynamics of the Te'rminos Lagoon, Mexico: observations and 3D numerical modelling. Ocean Dyn. 2014, 64, 1349-1371.

19. Diario Oficial. 2019. Norma oficial Mexicana. NOM-117-SSA1-1994. Bienes y servicios. Método de prueba para la determinación de cadmio, arsénico, plomo, estaño, cobre, fierro, zinc y mercurio en alimentos, agua potable y agua purificada por espectrometría de absorción atómica. Pubicado en el Diario Oficial de la Federación el 16 de agosto de 1995. México, D.F. Available online

https://www.sinec.gob.mx/SINEC/Vista/Normalizacion/DetalleNorma.xhtml?pidn=ZlhiVk5Te VEzNEE1RVVPci96Y3I4Zz09 (verified on July 3, 2019).

20. Hakanson, L. An ecological risk index for aquatic pollution control. A sedimentological approach," Water Research. 1980,14(8), 975-1001.

21. Martin, G. D.; R, George.; P, Shaiju.; K, R. Muraleedharan.; S, M. Nair N Chandramohanakumar. Toxic Metals Enrichment in the Surficial Sediments of a Eutrophic Tropical Estuary (Cochin Backwaters, Southwest Coast of India). The ScientificWorld Journal, 2012. DOI:10.1100/2012/972839

22. Rezaie, Boroon. M H.; V, Toress.; S, Diaz.; T, Lazzaretto.; M, Tsang.; D, D. Deheyn. The Geochemistry of Heavy Metals in the Mudflat of Salinas de San Pedro Lagoon, California, USA. 2013. DOI: http://dx.doi.org/10.4236/jep.2013.41002

23. Tomlinson, D. C.; Wilson, J. G.; Harris, C. R.; Jeffrey, D. W. Problems in the assessment of heavymetal levels in estuaries and the formation of a pollution index. Helgoland Mar. Res. 1980, 33, 566-575.

24. Suresh, G.; Ramasamy, V.; Meenakshisundaram, V.; Venkatachalapathy, R.; Ponnusamy, V. Influence of mineralogical and heavy metal composition on natural radionuclide contents in the river sediments. Applied Radiation and Isotopes. 2011, 69, 1466-1474.

25. Müller, G. Index of geoaccumulation in sediments of the Rhine River. GeoJournal. 1969, 2(3), 108-118.

26. Müller, G. Chemical Decontamination of Dredged Mate- rials, Combustion Residues, Soil and Other Materials Contaminated with Heavy Metals. In: W. Wolf, J. Van deBrink and F. J. Colon, Eds., 2nd International TNO/ BMFT Conference on Contaminated Soil. 1988, 2, 1439-1442. 
27. Taylor, S. R.; McLennan, S. M. The Geochemical Evolution of the Continental Crust," Reviews of Geophysics. 1995, 33 (2), 241-265.

28. Förstner, U. A.; C Wolfgang, M. Kersten. "Sediment Criteria, Development," In. D. Heling, P. Rothe and U. Förstner, Eds., Sediments and Environmental Geoche- mistry. 1990, 1, 311-338. DOI: 10.1007/978-3-642-75097-7_18

29. Earthref. 2018. Referencia values. Available online at https://earthref.org/GERMRD/11/ (verified on January 28, 2019).

30. Huheey, J. E. Inorganic Chemistry: Principles of Structure and Reactivity. Longman Higher Education. New York. 1983.

31. Muller, G. Die Schwermetallbelstung der sedimente des Neckars und seiner Nebenflusse: eine estandsaufnahme. Chem. Zeitung. 1981,105, 157-164.

32. Duncan, A.E., de Vries, N. \& Nyarko, K. Water Air Soil Pollut (2018) 229: 272. https://doi.org/10.1007/s11270-018-3899-6

33. Grenz, C.; R, Fichez.; C, Álvarez-Silva.; L, Calva-Benítez.; P. Conan.; A. Contreras-Ruiz E.; L. Denis.; S. Díaz-Ruiz.; P. Douillet.; M.E. Gallegos-Martinez.; J.F. Ghiglione.; F.J. GutiérrezMendieta.; M. Origel-Moreno.; A.Z. Marquez-Garcia.; A. Muñoz-Caravaca.; M. Pujo-Pay.; R. Torres-Alvarado.; J. Zavala-Hidalgo. Benthic ecology of tropical coastal lagoons: Environmental changes over the last decades in the Te'rminos Lagoon, Mexico. C. R. Geoscience. 2017, 349, 319 329. Coastal and Shelf Science, Elsevier, 218. DOI: 10.1016/j.crte.2017.09.016

34. Aguilar, C. A.; Montalvo, C.; Rodríguez, L.; Cerón, J. G.; Cerón, R. M. American oyster (Crassostrea virginica) and sediments as a coastal zone pollution monitor by heavy metals. International Journal of Environmental Science and Technology. 2012, 9, 579-586. DOI: DOI: 10.1007/s13762-012-0078-y

35. Cuevas, Madrid. H.; L, Rosales. Hoz.; A, Z Márquez.; García A, Carranza. Edwards. Environmental assessment of a mangrove protected area in the southeast Gulf of Mexico through sediment core analysis. Environmental Earth Sciences. 2018, 77,73. DOI:10.1007/s12665017-7160-1

36. Páez-Osuna, F.; Valdez-Lozano, D.S.; Alexander, H.M.; Fernandez-Perez, H. Trace metals in the fluvial system of Te'rminos lagoon, Mexico. Mar. Pollut. Bull. 1987, 18, 294-297.

37. Conan, P.; Agab, M.; Calva-Benítez, L.G.; Chifflet, S.; Douillet, P.; Dussud, C.; Fichez, R.; Grenz, C.; Gutierrez Mendieta, F.; Origel-Moreno, M.; Pujo- Pay, M.; Rodrı' guez-Blanco, A.; Sauret, C.; Severin, T.; Tedetti, M.; Torres Alvarado, R.; Ghiglione, J.-F. Combining biogeochemical characterisation and microbial biomass and activities to assess pelagic cycling in a large and shallow tropical lagoon (Te'rminos Lagoon, Mexico). Biogeosciences. 2017, 14, 959-975.

38. Grenz C.; M. Moreno.; K. Soetaert.; L. Denis.; P. Douillet, et al.. 2019. Spatio-temporal variability in benthic exchanges at the sediment-water interface of a shallow tropical coastal lagoon (south coast of Gulf of Mexico). Estuarine, Coastal and Shelf Science, Elsevier. 2019, 218, 368-380. 10.1016/j.ecss.2019.01.012

39. ATSDR. Plomo. Resumen de Salud Pública Plomo CAS: 7439-92-1. Agencia para Sustancias Tóxicas y el Registro de Enfermedades. Departamento de Salud y Servicios Humanos de EE. UU., Servicio de Salud Pública. 2007. Available online at https://www.atsdr.cdc.gov/es/phs/es_phs13.pdf (verified Febreary 7, 2019).

40. Balakrishnan, T. A.; Sundaramanickam, S. Shekhar.; T, Balasubramanian. Distribution and seasonal variation of heavy metals in sediments of muthupet lagoon, southeast coast of India. Journal of Ecological Engineering. 2017, 16(3), 49-60. DOI: 10.12911/22998993/2805 
41. Ajima, M. N. O.; P. C, Nnodi.; O.A, Ogo.; G. S, Adaka.; D. I, Osuigwe.; D. C, Njoku. Bioaccumulation of heavy metals in Mbaa River and the impact on aquatic ecosystem. Environ Monit Assess. 2015,187, 768. DOI 10.1007/s10661-015-4937-0

42. Muciño-Márquez. R.E.; M.G. Figueroa-Torres.; A. Aguirre-León. Composición fitoplanctónica en los sistemas fluvio-lagunares Pom-Atasta y Palizada del este, adyacentes a la laguna de Términos Campeche, México. Acta biol. Colomb. 2014, 19(1), 63-84.

43. Shil, S. C.; M, S. Islam.; A, Irin.; T, R. Tusher.; M, E. Hoq. Heavy Metal Contamination in Water and Sediments of Passur River near the Sundarbans Mangrove of Bangladesh. J. Environ. Sci. \& Natural Resources. 2017,10(1), 15-19.

44. Salem, Z B.; N, Capellia.; X, Laffraya.; G, Elisea.; H, Ayadib.; L, Aleyaa. Seasonal variation of heavy metals in water, sediment and roachtissues in a landfill draining system pond (Etueffont, $\begin{array}{lllll}\text { France). Ecological 25-37. } & \text { Engineering. DOI: }\end{array}$ http://dx.doi.org/10.1016/j.ecoleng.2014.03.072

45. Cardoso, I.; J, P. Granadeiro.; H, Cabral. Cantidad y calidad de las presas bénticas en las principales zonas de alimentación de las planicies lodosas del estuario del Tajo: Implicaciones para las poblaciones de aves y peces. Ciencias Marinas. 2008, 34(3), 283-296.

46. Ghorbanzadeh, Zaferani S. Gh.; A, Machinchian. Moradi.; R, Mousavi. Nadushan.; A, R. Sari.; S, R. Fatemi. Distribution pattern of heavy metals in the surficial sediment of Gorgan Bay (South Caspian Sea, Iran). Iranian Journal of Fisheries Sciences. 2016, 15(3), 1144-1166.

47. Gati, G.; C, Pop.; F, Brudașcă.; A, E. Gurzău W.; M, Spînu. Assessment of the Heavy Metal Contamination in the Danube Delta from the Bioaccumulation Perspective. Global Journal of Human Social Science (B). 2013,13(8), 11-16.

48. ATSDR. Cadmio. Resumen de Salud Pública Cadmio CAS: 1306-19-0. Agencia para Sustancias Tóxicas y el Registro de Enfermedades. Departamento de Salud y Servicios Humanos de EE. UU., Servicio de Salud Pública. 2018. Available online at https://www.atsdr.cdc.gov/es/phs/es_phs5.html (verified on March 2, 2019).

49. Hounkpè, J. B.; N, C. Kélomè.; R, Adèchina.; R, N. Lawani. Assessment of heavy metals contamination in sediments at the lake of Ahémé in southern of Benin (West Africa). Journal of Materials and Environmental Sciences. 2017, 8 (12), 4369-4377.

50. López, Pérez.; M, E. M C.; Del Rincón, Castro.; C, Muñoz. Torres, G. M. L, Ruiz Aguilar.; Solís S Valdez.; G, A. Zanor. Evaluación de la contaminación por elementos traza en suelos agrícolas del suroeste de Guanajuato, México. Acta Universitaria. 2017, 27(6), 10-21.

51. Hasan A.B.; S. Kabir.; A.H.M. Selim-Reza.; M. Nazim-Zaman.; A. Ahsan.; M. Rashid. Enrichment factor and geo-accumulation index of trace metals in sediments of the ship breaking area of Sitakund Upazilla (Bhatiary-Kumira), Chittagong, Bangladesh. Journal of Geochemical Exploration. 2013, 125, 130-137. DOI: 10.1016/j.gexplo.2012.12.002

52. Mohiuddin, K. M.; H, M. Zakir; K, Otomo.; S, Sharmin.; N, Shikazono. Geochemical distribution of trace metal pollutants in water andsediments of downstream of an urban river. Int. J. Environ. Sci. Tech. 2010, 7 (1), 17-28.

53. Okan, Tuncer. G.; Fevzi, Y. Risk Assessment and Accumulation of Metals in Sediment of Köyceğiz Lagoon System, Turkey. Journal of Advances in Agriculture. 2016, 6 (1), 804-811.

54. Suresh, G.; Sutharsan, P.; Ramasamy, V.; Venkatachalapathy, R. Assessment of spatial distribution and potential ecological risk of the heavy metals in relation to granulqometric contents of Veeranam lake sediments, India. Ecotoxicology and Environmental Safety. 2012, 84, $117-124$. 
55. Nfon, E.; Cousins, IT.; Järvinen, O.; Mukherjee, AB.; Verta, M.; Broman, D. Trophodynamics of mercury and other trace elements in a pelagic food chain from the Baltic Sea. Sci Total Environ. Elsevier B.V. 2009, 407 (24), 6267-74.

56. Botello, V. A.; Villanueva, Susana.; Edith, Martínez. Metales y metaloides en praderas de pastos marinos de la laguna de Términos, Campeche. pp. 133-143 En: Aspectos socioambientales de la región de la laguna de Términos, Campeche. Ramos Miranda J., y G.J. Villalobos Zapata (eds). Universidad Autónoma de Campeche. 2015, 210.

57. Long, E. R.; D, D. Macdonald.; S, L. Smith.; F, D. Calder. "Incidence of adverse biological effects within ranges of chemical concentrations in marine and estuarine sediments," Environmental Management. 1995,19 (1). 81-97.

58. Xu Y.; Wu Y.; Han J.; Li P. The current status of heavy metal in lake sediments from China: Pollution and ecological risk assessment. Ecol Evol. 2017, 7, 5454-5466. DOI: 10.1002/ece3.3124

59. FEPA/WHO (Federal Government Protection Agency). Guidelines and standards for environmental pollution control in Nigeria. 2003. 238 p.

60. CCME (Canadian Council of Ministers of Environment). Canadian Sediment Quality Guidelines for the Protection of Aquatic Life. Cadmium. Canadian Council of Ministers of the Environment. 1999. Available online: http://ceqg-rcqe.ccme.ca/download/en/231. Accessed on 30 april 2019.

61. US EPA. U.S. Environmental Protection Agency. Screening level ecological risk assessment protocol for hazardous waste combustion facilities. Vol. 3, Appendix E: Toxicity reference values. EPA530-D99-001C. $1999 . \quad$ Available on: https://www.csu.edu/cerc/researchreports/documents/ScreeningLevelEcologicalRiskAssessme ntProtocolHazardousWasteCombustionFacilitiesVolume3.pdf

62. Buchman, M.F. NOAA screening quick reference tables. NOAA, OR\&R Report 08-1, Office of Response and Restoration. 2008. Seattle WA.

63. MacDonald, D. D.; Ingersoll, C. G.; \& Berger, T. A. Development and evaluation of consensusbased sediment quality guidelines for freshwater ecosystems. Archives of Environmental Contamination and Toxicology. 2000, 39 (1), 20-31. 